\title{
Rape and Constructions of Masculinity and Femininity
}

Remarks on Andreas Contribution in Politikon 6/2003

\section{Bettina Engels}

Bettina Engels has studied political science at Universität Bremen and Freie Universität Berlin, Germany, with special interest in feminist theory and gender-sensitive approaches to peace and conflict.

ABSTRACT: With her paper Rape as a War Crime (Politikon 6/2003, p. 55-69), Andrea Theocharis has put an issue on the agenda, which has long been missing in Politikon's discussions. I am grateful to Andrea for starting an important debate, which I would like to continue by giving some remarks to her contribution focusing on the gender constructionist dimension of rape in violent conflicts.

Agreeing with Andrea, I will argue that rape and sexual violence are not only systematic and strategic weapons in violent conflicts but gendered crimes which cannot be analyzed appropriately without theorizing social and cultural constructions of masculinity and femininity. I will outline how gender-blind approaches fail to meet the issue of rape in violent conflicts. By mentioning some exemplary empirical figures, I will show that rape in violent conflicts is neither a new phenomena nor can it be considered a by-product of war. It must be emphasized that rape is not an act of sexuality but a crime against human physical and psychical integrity. I will discuss gender-sensitive approaches, which analyze rape in violent conflicts. Special attention will be paid to the view of rape as an act of male violence against women, which has also been outlined by Andrea. I will then focus on the construction of hegemonic masculinity and the widely ignored fact that also men are victims of rape and sexual torture in violent conflicts. I will conclude with emphasizing that constructions of femininity and masculinity are integral to violent conflicts in general and to rape and sexual violence in particular. If mainstream conflict analysis continues to ignore the dimensions of gender constructions, it will fail to meet its subject appropriately.

Gender-blind research and rape in violent conflicts

After The debate in mainstream conflict analysis about rape and sexual violence is above all characterized by its non-existence. As Andrea observes, rape in violent conflicts has been considered a normal by-product of war (Theocharis 2003: 55). It is also widely ignored in academic literature dealing with peace and conflict studies. Frequently, rape is explained and apologized by the assumption of a normal sexual drive of men and missing military discipline (Crawley
2000: 95; Nordstrom 1997: 16; Brownmiller 1978: 52). It is remarkable that hardly any-one no longer tries to explain the occurrence of violent conflicts as such using socio-biological approaches. However, as soon as sexual violence is concerned, these approaches are still popular (Seifert 1993: 67).

One example of recent academic debates is Herfried Münklers (2002) book about the new wars. Among other points, Münkler sees the new wars marked by the resexualization of the use of violence. (Münkler 2002: 
30; translation $\mathrm{BE}$ ). His thesis is founded (among others) on the assumption that rape had dramatically increased in the new wars which are no longer fought by national states and their militaries but increasingly by non- and sub-state actors (Münkler 2002: 250, Fn. 41).

There is no systematical empirical work on rape in violent conflicts, and existing data are not reliable (Lindsey 2000: 564), so Münklers supposition of the dramatic increase of rape cannot be confirmed nor rejected by empirical data (see Seifert 1993: 67). Existing works suggest that rape and sexual torture against both women and men have always been integral parts of violent conflicts, no matter of historical or cultural context (Nordstrom 1997: 28; Stiglmayer 1993: 110; Brownmiller 1978: 199208). Some exemplary figures are mentioned here to show that rape in violent conflicts can be considered neither a new phenomena nor a byproduct of war (Lindsey 2000: 563).

Quantitative empirical data on rape in violent conflicts and methodological problems

Rape has always been a systematic and strategic weapon in war. In World War II, German soldiers committed systematical mass rape against women in Eastern Europe and Russia (Brownmiller 1978: 56-60). The NSarmy kept Jewish women in institutionalized and technicalbureaucratically administrated forced prostitution, which is equivalent to sexual slavery (Brownmiller 1978: 68f; Schmidt-Harzbach 1992: 29). In 1945, approximately two million German women have been raped by Sowjet soldiers (Turpin 1998: 5; for figures on Berlin see Johr 1992: 54).
During Indian-Pakistani refugee movement in 1947, about 75000 to 100000 women have been raped (Butalia 2001). It has been confirmed that US-soldiers committed rape during Vietnam war (Zipfel 2001: 8; Brownmiller 1978: 96-114). During the Pakistan/Bengal War, about 200,000 to 600,000 women have been raped by Pakistani soldiers in the years 1970 and 1971 (Copelon 1995: 197; Turpin 1998: 5; Goldstein 2001: 363; Lentin 1997: 19). In Bosnia, it has been estimated that 20,000 to 60,000 women and girls have suffered rape (Seifert 1993; Skjelsbæk 2001a: 53). There have been six rape camps in Bosnia (Skjelsbæk 2001a: 53). An estimated three Quarters of Rwandan women have experienced sexual violence during the genocide war (Bop 2001: 26f). Two Thirds of those who have been raped and survived have been infected with HIV (Bop 2001: 33).

It must be realized that data on rape and sexual violence if it is existing at all are rarely reliable. Existing statistics are based on the numbers of victims seeking help (Lindsey 2000: 564). It can be assumed that these present a minority because most people who experience rape and sexual violence in conflicts do not have any possibility to seek medical and/or psychological help, and if they have, they do not dare because of shame and fear of social stigmatization (Byrne 1995: 44).

Giving some exemplary quantitative figures on rape in violent conflicts, I do not suggest that quantity was equivalent with cruelty and urgency. It must be emphasized that each person being raped whether in war or peace times is one victim too many. 
Statistics should not become the main issue (Lindsey 2000: 564), but they demonstrate that rape and sexual violence have been present in old wars, too. Regarding the quantitative dimensions, it gets even more dubious that the majority of mainstream conflict analysis and practical conflict management ignores rape and sexual violence.

Rape is not an act of sexuality

Gender-blind approaches to rape in violent conflicts not only fail to acknowledge quantitative dimensions and historical and cross-cultural continuity of rape and sexual violence in conflicts. Also in most of these approaches, the assumption is inherent rape being an act of sexuality. This is also suggested with the expression resexualization used by Münkler (2002: 30). It is not only intuitive plausible that rape, torture and slavery do not have to do anything with sexuality; it has also been discussed in several studies. The analysis of criminal files shows that perpetrators commit rape regardless whether they have opportunities of sexual activity or not (Brownmiller 1978: 140; Grabner/Sprung 1999). In the perpetrators psyche, rape does not fulfil a sexual function but produces emotions of power due to the victims' humiliation and submission (Seifert 1993; Zirpins 1997: 55). Rape and sexual violence ought to be defined above all from the victims, not from the perpetrators perspective. Taking the emotions of the victim, rape cannot be seen as an act of sexuality but of severe violence and humiliation (Zirpins 1997: 55).
Gender-sensitive approaches to rape in violent conflicts

As Andrea has outlined, gendersensitive approaches show that women are raped in violent conflicts because they are considered symbols of collective identity (Theocharis 2003: 57f; see Cockburn 1998: 223; Copelon 1995: 204f; Sideris 2001: 148). Women bodies became symbolic battlefields where communicative messages are exchanged among men (Brownmiller 1978: 45; Baines 2003: 7f; Crawley 2000: 95). This also means that in times of crisis and violent conflicts, women are defined according to their reproductive capabilities and are put under pressure in their sexual and reproductive behaviour (Dowler 1997: 78f; Byrne 1996: 34; Papanek 1994: 46).

Rape, which aims explicitly at a pregnancy of the female victim to force women to bear an enemy child, are well known from the war in Bosnia (Copelon 1995: 204f). But conflict parties made use of the same strategy of forced pregnancy in several other conflicts which do not receive interest in public debates in Europe, for example in Mozambique (Turshen 2002), during the Ogoni Crisis in Nigeria (Ibeanu 2001), in Bangladesh, Liberia and Uganda (Rehn/Sirleaf 2002: 16).

During the war in former Yugoslavia, rape has turned into a powerful instrument in political discourses and the construction of collective identity and images of the enemy because of blaming the group of the Others for raping of the own women (Theocharis 2003: 61f; Skjelsbæk 2001a: 54). These discourses are based on the construction of women being men's property (Turshen 2001: 55; Pillay 
2001: 40) in general and men sexual property in particular (Brownmiller 1978: 196f). It is important to notice that the use and instrumentalisation of rape in violent conflicts for the discursive construction of a collective identity has not only occurred in former Yugoslavia. Discourses of the others raping a groups own women could be observed during German invasion in Belgium 1914 (Brownmiller 1978: 50), in Kashmir (Manchanda 2001: 108) and in the Middle East (Zalewski/Enloe 1995: 292). In Rwanda, discourses on mass rape during the time of the genocide led to the construction of ethnic identities of people who before did not even know if they were Hutu or Tutsi (Baines 2003: 11).

Rape as an act of male violence against women

Feminist approaches see a connection of rape in times of violent conflicts with sexist and patriarchal structures of power which are also omnipresent in times of peace. These structures and the logic of violent conflicts reinforce each other. Rape and sexual violence in conflicts are based on deeply rooted hierarchical social constructions of gender and power (Zwingel 2002: 178). Rape and sexual violence are no barbarities of war; they are committed likewise when violent conflicts in the public sphere are absent (Nordstrom 1997: 20). Male members of militaries and armed groups are just normal men who do in wars what they have always done before, everyone in his way, in his frame and with his aims (Stiglmeyer 1993: 111; translation $\mathrm{BE})$.

Rape and sexual violence in violent conflicts are based on a general social acceptance of violence against women. In most states, the rape of a woman committed by her husband is considered legitimate and legal. Violence is accepted in lots of social and cultural contexts as a disciplinary means against wives and daughters (Pillay 2001: 41). Approximately every forth woman suffers rape and sexual violence at home. In some countries, for example in Chile and Pakistan, the proportion of women experiencing rape and sexual violence is up to 80 percent (Nordstrom 1997: 26). These estimations by the UN include adult women only. Sexual violence against young girls is not considered in these statistics. Rates of domestic violence and rape at home are especially high during violent conflicts and often increase significantly in post-conflict societies (Rehn/Sirleaf 2002: 14f; Hague 1997: 50f).

In the US, about 2000 children die every year because of sexual abuse. About 140000 suffer severe injuries caused by sexual violence the majority is younger than four years (Nordstrom 1997: 9). Estimations dated in 1994 suppose that in India, every 54th minute a woman is being raped and every 102 nd minute a woman is killed for reasons of dowry (Chenoy/Vanaik 2001: 132). Only 45 percent of all states have integrated protection from domestic violence in national legislation (Rehn/Sirleaf 2002: 15).

If rape and sexual violence are nevertheless analyzed separately for times of war and peace, this must not and cannot mean that the one or the other was more legitimate or that it was more horrible for the victim (Sideris 2001: 146). Tina Sideris (2001) has shown with her analysis of qualitative interviews with women in 
Mozambique, who survived rape and fled, that women are affected differently by rape in contexts of violent conflicts and rape as a civil crime in times of peace. However, it must be emphasized that rape and sexual violence are always crimes against the physical and psychical integrity of human beings and can never be legitimated in which context ever and by whom ever they are committed.

Hegemonic masculinity and rape in violent conflicts

Constructions of gender culturally constructed assumptions on how women and men are and social norms on how they should be are the strongest cultural support of military groups (Seifert/Eifler 1999: 10). They are reflected in the use of genderspecific military language. Constructions of masculinity in military context are not only rooted in the myths of the protector and the exclusion of women. They are also based on a concept of hegemonic masculinity that is characterized by heterosexual masculinity and therefore excludes homosexual men (Seifert 2002: 54). The likelihood to rape is significant higher for men in uniform than for civil men (Nordstrom 1997: 2

. Collective identity as it is constructed within military groups leads to the loss of individual identity. This permits violence to escalate and the individual men to commit acts of violence because he is not obliged to identify himself with the act (Hague 1997: 57). These constructions are inherent in violence in conflicts in general and for rape and sexual violence in particular. Rape is founded on gender constructions, which connect masculinity with power, dominance, force and aggression and femininity with passivity, subordination and the role of the protected and the victim (Hague 1997: 50). Rape in violent conflicts is directed against all human beings who do not fit in the concept of hegemonic masculinity: women, homo- and transsexual men, marginalized groups and the enemy (Hague 1997: 59). Sexual violence serves the strategic aim of the manifestation of militarized hegemonic masculinity (Skjelsbæk 2001b: 217).

Military brothels and models of sexual slavery were developed based on a construction of hegemonic and sexualized masculinity, which include the myths of the natural sexual drive (Copelon 1995: 204f). Parts of military elites believe in stopping soldiers go too far and commit rape by offering them sexual satisfaction through prostitutes and sexually enslaved women. Needless to say that these plans fail (Brownmiller 1978: 96f). Military brothels are also used to motivate and reward soldiers (Copelon 1995: 204f). It must be noticed that the lines between forced prostitution and sexual slavery using direct violence at the one side and prostitution resulting of constraints of structural violence on the other side are fluid (Copelon 1995: 204f; see Enloe 1990).

Rape of men in violent conflicts

The fact that men are also being raped in violent conflicts is widely ignored although its perpetration is confirmed for several conflicts (Zarkov 2001, 1997 for the former Yugoslavia; Hague 1997; Krog 2001 for South Africa; Mazurana/McKay 2001 for Uganda and Liberia). UN-reports document numerous cases of rape and 
other forms of sexual violence and torture against men during the war in former Yugoslavia used systematically by all parties involved in the conflicts (Zarkov 2001: 71).

This must be included in the analysis not for ignoring the fact for rape being an act of violence committed by men against mostly women but for revealing constructions of masculinity and femininity which are inherent in violent conflicts in general and sexual violence in particular. Rape is a crime of gender, of which nearly all but not all victims are women and all perpetrators are men. Sexual violence against men has a different meaning of sexual violence against women but both are based on constructions of gender (Zarkov 1997: 146).

Cordula Reimann (2000) considers rape of men as an act among men. It is a symbolic act of violence, which aims at the degradation, and entmasculinization of a man from the enemy group by constructing him as female or gay as unmanly (Zarkov 1997: 144; Goldstein 2001: 359). The construction defines the victim as gay but the perpetrator as manly, powerful and potent because he takes hold of the aggressive, dominant and therefore masculine position (Skjelsbæk 2001b: 225; Hague 1997: 55; Byrne 1995: 26). Constructions of hegemonic masculinity are always construction of heterosexual masculinity, too, especially in a military context (Zarkov 1997: 144). The construction of the male rape victim as gay is therefore equivalent with his symbolic entmasculinization.

Sexual violence against men occurs in different forms. If men are forced violently to rape other men, both victims are constructed as homosexual and therefore entmasculinized (Hague 1997: 55; Zarkov 2001: 79). Dubravka Zarkov (2001: 77) considers especially the act of castration as an expression of the phallocentric construction of masculinity. Susan Brownmiller (1978) has analyzed reports on rape of men in prisons and emphasizes that rape and violence is acts of neither sexuality in general nor homosexuality in particular but of power and submission (Brownmiller 1978: 174-184).

In her analysis of Croatian media, Dubravka Zarkov (2001) shows that rape of men is nearly invisible in public debates although there are no doubts on its existence. Rape of women seems to be newsworthy, rape of men seem to be not (Zarkov 2001: 72, 81). Antjie Krog observes the same in her analysis of the South African Truth and Reconciliation Com-mission. Male victims of sexual violence and torture do not speak about rape. Rape is considered a women thing (Krog 2001: 207). If rape of men is noticed at all, it is considered an act of violence while rape of women is still considered an act of sexuality (Krog 2001: 207). The invisibility of male rape victims in the public as well as in academic debates is related to the construction of heterosexual hegemonic masculinity, which is integral to all constructions of collective identity (Zarkov 1997: 145).

Dubravka Zarkov shows that if the Croatian media reports at all about sexual violence against men; they always present Serbs as the perpetrators and Muslims as the victims (Zarkov 2001: 81). Rape and sexual violence against men is presented as if it had nothing to do at 
all with the men of the own group, Croatian men. This shows how the constructions of the ethnic Self is orientated at the norm of heterosexual masculinity.

\section{Conclusion}

Rape and sexual violence are empirical phenomena, which are inherent in all violent conflicts. They are based on constructions of militarized hegemonic masculinity, which also form the basis of the social institution of the military (Hague 1997: 55; Turshen 2001: 59). Rape and sexual violence are parts of the gender dimension of violent conflicts regardless if they, in addition, are part of a genocide or ethnic cleansing (Copelon 1995).

Rape in violent conflicts is always a crime against humanity and against the physical and psychical integrity of the victim. It is theoretically and empirically an act of torture: It follows the same logic and it has the same consequences for the victims (Seifert 1993: 70). Rape is strongly related to hierarchical social gender relations that exist likewise in times of war and peace.

The empirical phenomena of rape and sexual violence show that constructions of masculinity and femininity are integral parts of violent conflicts. If conflict analysis ignores the gender dimension, it fails to meet its subject appropriately. After putting rape and sexual violence on the agenda in general, now a systematically differentiation of the contexts in which rape in violent conflicts occur is required (Turshen 2001: 55).

If it is accepted that rape is a systematic weapon and strategy in violent conflicts, this has the important implication that rape is not a fixed fact but changeable (Turshen 2001). Conflict management is challenged to develop concepts for the prevention of rape and sexual violence, for ending the perpetrators impunity and for effective help for the victims. These concepts must include short-term medical and long-term psychological help, social transformative instruments to stop social stigmatization of rape victims and assistance for victims to get over the feeling of helplessness, powerlessness and passivity. 
References:

Baines, Erin 2003: Rwanda and the Politics of the Body. Working Paper No. 39, Centre of International Relations, University of British Columbian, August 2003. http://www.iir.ubc.ca/webWP39.doc

Bop, Codou 2001: Women in Conflicts, Their Gains and Their Losses. In: Sheila Meintjes/Ann Pillay/Meredeth Turshen (eds.), The Aftermath. Women in Post-Conflict Transformation. London/New York: Zed Books, S. 19-34.

Brownmiller, Susan 1978: Gegen unseren Willen. Vergewaltigung und Männerherrschaft. Frankfurt am Main: S. Fischer. [Original: Against Our Will: Men, Women and Rape. New York: Simon and Schuster, 1975].

Butalia, Urvashi 2001: Women and Communal Conflict: New Challenges for the Womens Movement in India. In: Caroline O.N. Moser/ Fiona C. Clark (eds.), Victims, Perpetrators or Actors Gender, Armed Conflict and Political Violence. London/New York: Zed Books, S. 99-113.

Byrne, Bridget 1995: Gender, conflict and development. Volume I: Overview. Bridge Report No. 34. Brighton: University of Sussex, December 1995 (revised July 1996).

Carver, Terrell 1996: Gender is not a Synonym for Women. Boulder/London: Lynne Rienner.

Chenoy, Anuradha Mitra/Vanaik, Achin 2001: Promoting Peace, Security and Conflict Resolution: Gender Balance in Decision making. In: Inger Skjelsbæk/Dan Smith (eds.),Gender, Peace and Conflict. London u.a.: Sage, S. 122138.

Cockburn, Cynthia 1998: The Space Between Us. Negotiating Gender and National Identities in Conflict. London/New York: Zed Books.

Cohn, Carol 1993: Wars, Wimps, and Women: Talking Gender and Thinking War. In: Miriam Cooke/Angela Woollacott (eds.), Gendering War Talk. Princeton: Princeton University Press, S. 227-246.

Cohn, Carol 1989: Emasculating Americas Linguistic Deterrent. In: Adrienne Harris/Ynestra King (eds.), Rocking the Ship of State: Toward a Feminist Peace Politics. Boulder u.a.: Westview Press, S. 153-170.

Copelon, Rhonda 1995: Gendered War Crimes: Reconceptualizing Rape in Time of War. In: Julie Peters/Andrea Wolper (eds.), Womens Rights Human Rights: International Feminist Perspectives. London/New York: Routledge, S. 197-214.

Crawley, Heaven 2000: Engendering the State in Refugee Womens Claim for Asylum. In: Susie, Jacobs/Ruth Jacobson/Jennifer Marchbank (eds.), States 
of Conflict: Gender, Violence and Resistance. London/New York: Zed Books, S. 87-104.

Dowler, Lorraine 1997: The Mother of all Warriors: Women in West Belfast, Northern Ireland. In Ronit Lentin (eds.), Gender and Catastrophe. London/New York: Zed Books, S. 77-90.

Enloe, Cynthia 1990: Bananas, Beaches and Bases. Making Feminist Sense of International Politics. Berkley u.a.: University of California Press.

Galtung, Johan 1975: Strukturelle Gewalt. Reinbek bei Hamburg: Rowohlt.

Gleditsch, Nils Petter/Strand Håvard/Eriksson, Mikael/Sollenberg, Margareta/ Wallensteen, Peter 2001: Armed Conflict 1945-99: A New Dataset. Paper prepared for session WB08 New Data on Armed Conflict, 42nd Annual Convention of the International Studies As-sociation, Chicago, IL, 20-24 February 2001.

Goldstein, Joshua S. 2001: War and Gender. How Gender Shapes the War System and Vice Versa. Cambridge/New York: Cambridge University Press.

Grabner, Kerstin/Sprung, Annette 1999: Krieg und Vergewaltigung. In: Barbara Hey/Cécile Huber/Karin M. Schmidlechner (eds.), Krieg: Geschlecht und Gewalt. Graz: Leykam, S. 161-176.

Hague, Euan 1997: Rape, Power and Masculinity: The Construction of Gender and National Identities in the War in Bosnia-Herzegovina. In: Ronit Lentin (eds.), Gender and Catastrophe. London/New York: Zed Books, S. 50-63.

Ibeanu, Okechukwu 2001: Healing and Changing: The Changing Identity of Women in the Aftermath of the Ogoni Crisis in Nigeria. In: Sheila Meintjes/Ann Pillay/Meredeth Turshen (eds.), The Aftermath. Women in Post-Conflict Transformation. London/New York: Zed Books, S. 189-209.

Johr, Barbara 1992: Die Ereignisse in Zahlen. In: Helke Sander/Dies. (eds.), Befreier und Befreite. Krieg, Vergewaltigung, Kinder. München: Antje Kunstmann, S. 46-73.

Jones, Daniel M./Bremer, Stuart A./Singer, David J. 1996: Militarized Interstate Disputes, 1816-1992: Rationale, Coding Rules, and Empirical Patterns. In: Conflict Management and Peace Science Vol. 15, No. 2, S. 163-215.

Kaldor, Mary 2000: Neue und alte Kriege. Organisierte Gewalt im Zeitalter der Globalisierung. Frankfurt am Main: Suhrkamp. [Original: New \& Old Wars: Organized Violence in a Global Era. 1999.]

Krog, Antjie 2001: Locked into Loss and Silence: Testimonies of Gender and Violence at the South African Truth Commission. In: Caroline O.N. Moser/ Fiona C. Clark (eds.), Victims, Perpetrators or Actors Gender, Armed Conflict and Political Violence. London/New York: Zed Books, S. 203-216.

Lentin, Ronit 1997: Introduction: (En)gendering Genocides. In: Dies. (eds.), Gender and Catastrophe. London/New York: Zed Books, S. 2-17. 
Lindsey, Charlotte 2000: Women and War. In: International Review of the Red Cross Vol. 839, S. 561-580.

Manchanda, Rita 2001: Ambivalent Gains in South Asian Conflicts. In: Sheila Meintjes/Ann Pillay/Meredeth Turshen (eds.), The Aftermath. Women in Post-Conflict Transformation. London/New York: Zed Books, S. 99-121.

Mazurana, Dyan/McKay, Susan 2001: Child Soldiers: What about the girls In: Bulletin of the Atomic Scientist Vol. 57, No. 5, S. 30-35.

Münkler, Herfried 2002: Die neuen Kriege. Reinbek bei Hamburg: Rowohlt.

Nicholson, Linda 1994: Interpreting Gender. In: Signs. Journal of Women in Culture and Society Vol. 20, No. 1, S. 79-105.

Nordstrom, Carolyn 1997: Girls and War zones. Troubling Questions. Uppsala: Life \& Peace Institute.

Papanek, Hanna 1994: The Ideal Women and the Ideal Society: Control and Autonomy in the Construction of Identity. In: Valentine M. Moghadam (eds.), Identity Politics and Women. Cultural Reassertions and Feminisms in International Perspectives. Boulder u.a.: Westview Press, S. 42-75.

Peterson, V. Spike/Runyan, Anne Sisson 1993: Global Gender Issues. Boulder u.a.: Westview Press.

Pillay, Ann 2001: Violence against Women in the Aftermath. In: Sheila Meintjes/Ann Pillay/Meredeth Turshen (eds.), The Aftermath. Women in PostConflict Transformation. London/New York: Zed Books, S. 35-45.

Rehn, Elisabeth/Sirleaf, Ellen Johnson 2002: Women, War and Peace: The Independent Experts Assessment on the Impact of Armed Conflict on Women and Womens Role in Peace-building. New York: UNIFEM.

Reimann, Cordula 2000: Frauen als Akteurinnen in und nach gewaltsamen Konflikten. In: Kein Krieg ohne Frauen ohne Frauen kein Frieden Dokumentation einer Fachtagung der Friedrich-Ebert-Stiftung mit dem Marie-Schlei-Verein am 13. November 2000 in Bonn.

http://library.fes.de/fulltext/iez/00968.html\#Reimann

Schmidt-Harzbach, Ingrid 1992: Eine Woche im April. Berlin 1945. In: Helke Sander/Barbara Johr (eds.), Befreier und Befreite. Krieg, Vergewaltigung, Kinder. München: Antje Kunstmann, S. 21-45.

Seifert, Ruth 2002: Identität, Militär und Geschlecht. Zur identitätspolitischen Bedeutung einer kulturellen Konstruktion. In: Karin Hagemann/Stefanie Schüler-Springorum (Hrsg.), Heimat-Front. Militär und Geschlechterverhältnisse im Zeitalter der Weltkriege. Frankfurt am Main: Campus, S. 53-66.

Seifert, Ruth 1993: Die Zweite Front Zur Logik sexueller Gewalt in Kriegen. In: S + F Vierteljahresschrift für Sicherheit und Frieden, Jg. 11, Heft 2, S. 66-71. 
Seifert, Ruth/Eifler, Christine 1999: Einleitung. In: Christine Eifler/Ruth Seifert (eds.), Soziale Konstruktion- Militär und Geschlechterverhältnis. Münster: Westfälisches Dampfboot, S. 7-16.

Skjelsbæk, Inger 2001a: Is Femininity Inherently Peaceful The Construction of Femininity in War. In: Dies./Dan Smith (eds.),Gender, Peace and Conflict. London u.a.: Sage, S. 47-67.

Skjelsbæk, Inger 2001b: Sexual Violence and War: Mapping Out a Complex Relationship. In: European Journal of International relations Vol. 7, No. 2, S. 211-237.

Sideris, Tina 2001: Rape in War and Peace: Social Context, Gender, Power and Identity. In: Sheila Meintjes/Ann Pillay/Meredeth Turshen (eds.), The Aftermath. Women in Post-Conflict Transformation. London/New York: Zed Books, S. 142-158.

Stiglmayer, Alexandra 1993: Vergewaltigungen in Bosnien-Herzegowina. In: Dies. (eds.), Massenvergewaltigung. Krieg gegen die Frauen. Freiburg (Breisgau): Kore, S. 109-216.

Theocharis, Andrea 2003: Rape As a War Crime. A Critical Perspective on International Responses after the War in Yugoslavia and Rwanda. In: Politikon Issue 6, p. 55-69.

Turpin, Jennifer 1998: Many Faces: Women Confronting War. In: Lois Ann Lorentzen/Jennifer Turpin (eds.), The Women and War Reader. New York/London: New York University Press, S. 3-18.

Turshen, Meredeth 2001: Engendering Relations of State to Society in the Aftermath. In: Sheila Meintjes/Ann Pillay/Meredeth Turshen (eds.), The Aftermath. Women in Post-Conflict Transformation. London/New York: Zed Books, S. 78-96.

Wasmuht, Ulrike C. 2001: Gender und Krieg. Über den Zusammenhang zwischen Weiblichkeit und Kriegsakzeptanz und Männlichkeit und Kriegsbereitschaft. In: Österreichisches Studienzentrum für Frieden und Konfliktbearbeitung (eds.), Nach der Jahrtausendwende: zur Neuorientierung der Friedensforschung. Friedensbericht 2001, Ergebnisse, der State-of-Peace-Konferenz. Münster: Agenda, S. 168-188.

Zalewski, Marysia/Enloe, Cynthia 1995: Questions about Identity in International Relations. In: Ken Booth/Steve Smith (eds.), International Relations Theory Today. University Park: The Pennsylvania State University Press, S. 279305.

Zarkov, Dubravka 2001: The body of the Other Man: Sexual Violence and the Construction of Masculinity, Sexuality and Ethnicity the Croatian Media. In: Caroline O.N. Moser/ Fiona C. Clark (eds.), Victims, Perpetrators or Actors Gender, Armed Conflict and Political Violence. London/New York: Zed Books, S. 69-82. 
Zarkov, Dubravka 1997: War rapes in Bosnia: On Masculinity, Femininity and the Power of the Rape Victim Identity. In: Tijdschrift voor Criminologie, Vol. 39, No. 2, S. 140-151.

Zipfel, Gaby 2001: Blood, sperm and tears. Sexuelle Gewalt in Kriegen. In: Eurozine. http://www.eurozine.com/article/2001-11-27-zipfel-de.html.

Zirpins, Cornelia 1997: Vergewaltigung Analyse eines Kriegsverbrechens. In: Wissenschaft und Frieden 2, S. 54-58.

Zwingel, Susanne 2002: Was trennt Krieg und Frieden Gewalt gegen Frauen aus feministischer und völkerrechtlicher Perspektive. In: Cilja Harders/Bettina Roß (eds.), Geschlechterverhältnisse in Krieg und Frieden. Perspektiven der feministischen Analyse internationaler Beziehungen. Opladen: Leske + Budrich, S. $175-188$ 